\title{
Tolerance of melon cultivars to irrigation water salinity
}

\author{
Francisco A. de L. Pereira ${ }^{1}$, José F. de Medeiros ${ }^{2}$, Hans R. Gheyi ${ }^{3}$, \\ Nildo da S. Dias ${ }^{2}$, Welka Preston ${ }^{4} \&$ Cybelle B. e L. Vasconcelos ${ }^{5}$ \\ ${ }^{1}$ Universidade Federal Rural do Semi-Árido/Centro Multidisciplinar de Caraúbas. Caraúbas, RN. E-mail: aecio@ufersa.edu.br \\ ${ }^{2}$ Universidade Federal Rural do Semi-Árido/Centro de Ciências Agrárias/Departamento de Ciências Agronômicas e Florestais. Mossoró, RN. E-mail: \\ jfmedeir@ufersa.edu.br; nildo@ufersa.edu.br (Corresponding author) \\ ${ }^{3}$ Universidade Federal do Recôncavo da Bahia/Centro de Ciências Agrárias, Ambientais e Biológicas/Núcleo de Engenharia de Água e Solo. Cruz das Almas, BA. \\ E-mail: hans@pq.cnpq.br \\ ${ }^{4}$ Universidade Federal Rural do Semi-Árido/Centro de Ciências Agrárias/Programa de Pós-graduação em Manejo de Solo e Água. Mossoró, RN. E-mail: \\ welkapreston@hotmail.com \\ ${ }^{5}$ Universidade Federal Rural do Semi-Árido/Centro de Engenharia/Departamento de Engenharia e Ciências Ambientais. Mossoró, RN.E-mail: cybelle@ufersa.edu.br
}

\section{Key words:}

relative crop yield

water quality

salt stress

Cucumis melo L.

\begin{abstract}
A B S T R A C T
The use of saline water for irrigation causes severe restriction to nutritional balance, growth and production in many crops due to the effect of salts on plant and soil. The objective of this study was to investigate the response of melon (Cucumis melo L.) cultivars to various levels of irrigation water salinity on yield and fruit quality. A field experiment was conducted in a split-plot randomized block design with four replicates. The factors were five levels of irrigation water salinity $\left(0.54,1.48,2.02,3.03\right.$ and $\left.3.90 \mathrm{dS} \mathrm{m}^{-1}\right)$ in the plots and five melon cultivars $\left(\mathrm{C}_{1}\right.$ - Sancho - Pele de sapo; $\mathrm{C}_{2}$ - Medellín - Pele de sapo; $\mathrm{C}_{3}$ - Mandacaru - Canary; $\mathrm{C}_{4}$ - Néctar - Galia; $\mathrm{C}_{5}$ - Sedna - Cantaloupe) in the sub-plots. According to the results, among the five genotypes studied, Sancho was the most salt-tolerant genotype, followed by Mandacaru, Medellín, Sedna and Néctar. Since irrigation water salinity did not influence the mean fruit weight, the reduction in the number of fruits was the main cause of yield reduction of the melon crop under high salinity water. The contents of total soluble solids increased under high salinity level.
\end{abstract}

\section{Palavras-chave:}

rendimento relativo da cultura qualidade de água

estresse salino

Cucumis melo L.

\section{Tolerância de cultivares de melão à salinidade da água de irrigação}

\section{R E S U M O}

O uso de água salina na irrigação causa severas restrições no equilíbrio nutricional, crescimento e produção de muitas culturas devido aos efeitos dos sais sob o solo e a planta. Assim, objetivou-se investigar a resposta de cultivares de melão (Cucumis melo L.) em vários níveis de salinidade da água de irrigação sob a produção e a qualidade de frutos. Um experimento em campo foi conduzido em delineamento experimental em blocos casualizados, em parcelas subdivididas com quatro repetições. $O$ fator das parcelas foram os níveis de salinidade da água de irrigação $\left(0,54 ; 1,48 ; 2,02 ; 3,03\right.$ e $\left.3,90 \mathrm{dS} \mathrm{m}^{-1}\right)$ e das subparcelas, cinco cultivares de melão $\left(C_{1}\right.$ - Sancho - Pele de sapo; $C_{2}$ - Medellín - Pele de sapo; $C_{3}$ - Mandacaru - Canary; $\mathrm{C}_{4}$ - Néctar - Galia; $\mathrm{C}_{5}$ - Sedna - Cantaloupe). As análises dos resultados indicaram que entre as cinco cultivares estudadas, a Sancho foi a mais tolerante à salinidade da água de irrigação, seguida das cultivares Mandacaru, Medellín, Sedna e Néctar. Uma vez que a salinidade não influenciou o peso médio dos frutos, a redução do número de frutos por planta foi a maior causa da perda de produtividade de melão nas cultivares sensíveis à salinidade. Os teores de sólidos solúveis totais dos frutos de melão aumentaram com os níveis de salinidade da água. 


\section{INTRODUCTION}

Melon production in Rio Grande do Norte is concentrated in the microregion of Mossoró, specifically on the Apodi Plateau, encompassing the semi-arid region close to the coast. The main factors favoring the production and quality of melon fruits are the adequate edaphoclimatic conditions of the region.

Although irrigation is pointed as one of the alternatives for the socioeconomic development of the Mossorós producing region, it is limited by the low availability of water. Thus, water management and use efficiency are essential for a sustainable cultivation, since irrigation consumes a large volume of goodquality surface water.

Additionally, ground waters used for irrigation in the semiarid region are frequently saline and their use has adverse effects on soil, water and plants, causing severe restrictions to physiological activities and productive capacity of crops (Plaut et al., 2013; Kim et al., 2016). At high salinity level, the vegetative growth, cell surface expansion and primary carbon metabolism of many crops are negatively affected by osmotic stress, water deficit, nutritional imbalance and oxidative stress (Kim et al., 2008).

Many studies indicate that sensitivity and tolerance of crops to the effects of water salinity may vary among species and cultivars of a same species, and also depend on the climatic conditions of the region, type of soil, method of irrigation, plant development stage, among others (Aragão et al., 2009; Dias et al., 2011; Nangare et al., 2013; Medeiros et al., 2014).

Knowledge on the adverse effects of salts and irrigation management, along with interpretation and analysis of the limits of tolerance to salinity of plant species, under certain edaphoclimatic conditions, are fundamental in the adequate choice of crop and cultivar to be exploited in agricultural areas when saline water is available for irrigation, in order to avoid salinization of the areas and guarantee commercial production.

Therefore, this study aimed to investigate the responses of melon cultivars to different levels of irrigation water salinity in order to select species that are sensitive and tolerant to the effects of salts.

\section{Material AND Methods}

The study was carried out from November 2009 to January 2010, at the experimental field of the Pedra Preta Farm, situated to the right of BR-304 RN highway, $\mathrm{km} \mathrm{13}$, in the municipality of Mossoró, RN (4'39'39” S; $37^{\circ} 23^{\prime}$ ' 13” W; at altitude of $34 \mathrm{~m}$ ).
The experimental plots consisted of 20-m-wide, 30-m-long blocks with four replicates, totaling a useful area of 0.48 ha. Two sources of water were used, extracted through tubular wells: one was calcareous, with high salinity level $\left(3.90 \mathrm{dS} \mathrm{m}^{-1}\right)$, at depth of $100 \mathrm{~m}$, and the other one from Açu sandstone, with low salinity level $\left(0.57 \mathrm{dS} \mathrm{m}^{-1}\right)$ at depth of $1000 \mathrm{~m}$. Samples from both water sources were collected for physical-chemical characterization according to the methodology of Richards (1954) (Table 1).

The soil, classified as Yellow Argisol, was prepared 30 days before transplanting, by harrowing, subsoiling, opening of furrows and raising of ridges. Soil samples from the layers of $0-15,15-30$ and $30-45 \mathrm{~cm}$ were collected before preparing the area for physical-chemical characterization (Table 2). Analyses were carried out at the Laboratory of Irrigation and Salinity of the Department of Environmental and Technological Sciences of the Federal University of the Semi-Arid Region (UFERSA) and at the Laboratory of Irrigation and Salinity of the Federal University of Campina Grande (UFCG), according to methodology proposed by EMBRAPA (1997).

The experiment was set in a split-plot randomized complete block design in 5 x 5 factorial scheme (salinity x cultivars), with 4 replicates, totaling 100 experimental units. Treatments were formed by the combination of two factors: five levels of irrigation water salinity in the plots $\left(\mathrm{S}_{1}=0.54 ; \mathrm{S}_{2}=1.48 ; \mathrm{S}_{3}=\right.$ 2.02; $\mathrm{S}_{4}=3.03$ and $\mathrm{S}_{5}=3.9 \mathrm{dS} \mathrm{m}^{-1}$ ) and five melon cultivars in the subplots $\left(\mathrm{C}_{1}\right.$ - Sancho - Pele de sapo; $\mathrm{C}_{2}$ - Medellín - Pele de sapo; $\mathrm{C}_{3}-$ Mandacaru - Canary; $\mathrm{C}_{4}-$ Néctar - Galia; $\mathrm{C}_{5}$ - Sedna - Cantaloupe)

Saline concentrations were obtained by mixing water of high $\left(3.9 \mathrm{dS} \mathrm{m}^{-1}\right)$ and low $\left(0.54 \mathrm{dS} \mathrm{m}^{-1}\right)$ salinity levels. The salinity level $\mathrm{S}_{3}$ resulted from the mixture of $50 \%$ of $\mathrm{S}_{1}$ and $\mathrm{S}_{5}$ waters, whereas the average values of $S_{1}$ with $S_{3}$ and $S_{5}$ with $S_{3}$ formed $S_{2}$ and $S_{4}$, respectively. The waters were mixed at the control head of the irrigation system, by regulating the valves, and applied through an independent system of conduction and irrigation for each treatment, avoiding alterations in their salinity.

Each plot consisted of four 6-m-long rows spaced by $2 \mathrm{~m}$; the two central rows were used for evaluation and the two side rows were considered as borders. Plants were spaced by $0.4 \mathrm{~m}$, totaling 15 plants in each row. Two of these plants were eliminated from the end of each row, leaving 22 plants for the evaluation of production and quality of fruits.

Melon seeds were sown on trays with 200 cells containing coconut fiber and, after irrigated, stored in germination chamber. After emergence, the seedlings were transferred to a nursery

Table 1. Physical-chemical characteristics of the waters used in the experiment

\begin{tabular}{|c|c|c|c|c|c|c|c|c|c|c|}
\hline Source & $\begin{array}{l}\mathrm{pH} \\
\mathrm{H}_{2} \mathrm{O}\end{array}$ & $\begin{array}{c}E C_{w} \\
d S m^{-1}\end{array}$ & $\mathrm{~K}^{+}$ & $\mathrm{Na}^{+}$ & $\mathrm{Ca}^{2+}$ & $\frac{\mathrm{Mg}^{2+}}{\mathrm{mmol}_{\mathrm{c}} \mathrm{L}^{-1}}$ & $\mathrm{Cl}^{-}$ & $\mathrm{CO}_{3}{ }^{2-}$ & $\mathrm{HCO}_{3}{ }^{-}$ & $\begin{array}{c}\text { SAR } \\
\left(\mathrm{mmol} \mathrm{L}^{-1}\right)^{0.5}\end{array}$ \\
\hline Açu - Deep well & 7.5 & 0.54 & 0.53 & 0.8 & 1.80 & 0.50 & 1.6 & 0.35 & 4.10 & 0.74 \\
\hline Jandaíra - Shallow well & 6.9 & 3.9 & 0.15 & 19 & 15.2 & 2.80 & 25.2 & 0.20 & 4.80 & 6.33 \\
\hline
\end{tabular}

Table 2. Physical-chemical characterization of the soil in the experimental area

\begin{tabular}{|c|c|c|c|c|c|c|c|c|c|c|c|}
\hline \multirow{2}{*}{$\begin{array}{l}\text { Layers } \\
\text { (cm) }\end{array}$} & \multirow{2}{*}{$\mathrm{pH}_{\mathrm{w}}$} & \multirow{2}{*}{$\begin{array}{c}\mathrm{EC}_{\text {se }} \\
\mathrm{dS} \mathrm{m}^{-1}\end{array}$} & \multirow{2}{*}{$\begin{array}{c}\rho_{\mathrm{s}} \\
\mathrm{g} \mathrm{cm}^{-3}\end{array}$} & $\mathrm{~K}^{+}$ & $\mathrm{Na}^{+}$ & $\mathrm{Ca}^{2+}$ & $\mathrm{Mg}^{2+}$ & CEC & Sand & Silt & Clay \\
\hline & & & & \multicolumn{5}{|c|}{$\mathrm{cmol}_{\mathrm{c}} \mathrm{dm}^{-3}$} & \multicolumn{3}{|c|}{$\mathrm{g} \mathrm{kg}^{-1}$} \\
\hline $0-15$ & 7.24 & 0.94 & 2.69 & 0.14 & 0.15 & 2.76 & 1.29 & 4.34 & 935.8 & 26.50 & 37.7 \\
\hline $15-30$ & 7.00 & 0.85 & 2.72 & 0.13 & 0.10 & 1.37 & 2.25 & 3.85 & 925.6 & 36.60 & 37.8 \\
\hline $30-45$ & 7.06 & 0.46 & 2.73 & 0.07 & 0.10 & 1.27 & 1.82 & 3.36 & 875.5 & 66.70 & 57.8 \\
\hline
\end{tabular}


with anti-aphid screen. Plants were transplanted at 12 days after sowing, when the second true leaf was fully expanded, on November 10, 2009.

A drip irrigation system was used, with polyethylene lateral lines and drippers fixed on the pipe wall. Main and lateral lines were projected independently, for each treatment, to avoid interference. Emitters were spaced at a distance of $0.30 \mathrm{~m}$ and had nominal flow rate of $1.50 \mathrm{~L} \mathrm{~h}^{-1}$ and mean flow rate of 1.35 $\mathrm{L} \mathrm{h}^{-1}$, with uniformity coefficient of $94 \%$.

Mean, maximum and minimum temperature along the experiment were $28.17,34.14$ and $24.15{ }^{\circ} \mathrm{C}$, respectively. In addition, the mean values of relative humidity (67\%), wind speed $\left(10 \mathrm{~m} \mathrm{~s}^{-1}\right)$ and global radiation $\left(21.48 \mathrm{MJ} \mathrm{m}^{-2}\right)$ were recorded. Regarding rainfall, measurements were taken inside the experimental area and, along the experiment, rainfall was equal to only $15 \mathrm{~mm}$ (65 days after transplanting - DAT).

Irrigation management was based on the climatic data of the period, estimating reference evapotranspiration (ETo) by the Penman-Monteith method (Allen et al., 1998), using the Kc determined by the dual Kc technique, determining ETc.

Basal fertilization consisted of $420 \mathrm{~kg} \mathrm{ha}^{-1}$ of the commercial formulation 6-24-12, which is equivalent to the application of $25.2,100.8$ and $50.4 \mathrm{~kg} \mathrm{ha}^{-1}$ of $\mathrm{N}, \mathrm{P}_{2} \mathrm{O}_{5}$ and $\mathrm{K}_{2} \mathrm{O}$, respectively. Top-dressing fertilizations were applied via fertigation, based on soil analysis and on recommendations of Medeiros et al. (2014), by applying the following quantities of nutrients: 81,93 and $188 \mathrm{~kg} \mathrm{ha}^{-1}$ of $\mathrm{N}, \mathrm{P}_{2} \mathrm{O}_{5}$ and $\mathrm{K}_{2} \mathrm{O}$, respectively.

Planting rows were covered with mulch to reduce phytosanitary problems and optimize water use. Until the beginning of flowering (25 DAT), plants were protected with geotextile to avoid the entry of insects. At the beginning of flowering, between 20 and 25 DAT, three bee hives were placed in the area to help in pollination.

Two harvests were performed between January 1 and 15, 2010. For the cultivars Mandacaru, Sedna and Néctar, harvests occurred at 60 and 65 DAT, whereas for Sancho and Medellín, at 65 and 70 DAT. Fruits were individually harvested from each plant, counted and weighed to determine the following parameters: fruit production (commercial and total), number of fruits per plant (commercial and total) and mean fruit weight (commercial and total).

Total soluble solids were evaluated in a digital refractometer, using the juice of one slice of fruit homogenized in a mixer. Before the destructive analysis of the fruit, firmness (texture) was determined by collecting three discs of the rind surface in the equatorial area, using a penetrometer with 8 -mm-diameter probe.

The tolerance parameters of the melon cultivars SL (salinity threshold) and b (relative yield loss per $\mathrm{dS} \mathrm{m}^{-1}$ ) were estimated by the methodology of Genuchten \& Gupta (1993). The results were subjected to analysis of variance; variables relative to the quantitative factor, water salinity levels, were evaluated through regression and means relative to the qualitative factor, melon cultivars, were compared by Tukey test at 0.05 probability level.

\section{Results AND Discussion}

\section{Production and production components}

According to the analysis of variance, production variables and production components were influenced by salinity, except mean fruit weight. In addition, salinity and the interaction salinity x cultivar had effect $(\mathrm{p}<0.05)$ on the variables total fruit weight and number of commercial fruits (Table 3 ).

The highest commercial and total production was obtained by the cultivar Medellín (41.81 and $50.12 \mathrm{Mg} \mathrm{ha}^{-1}$, respectively), although it did not differ statistically from the cultivar Sancho. Regarding production, the cultivar Mandacaru was statistically equal to Sancho and superior to Néctar and Sedna, the latter was superior to Galia (Table 3).

The cultivars of Néctar and Sedna showed higher number of commercial fruits per plant (more than 2 fruits plant ${ }^{-1}$ ), being superior to the others. For the total number of fruits, the

Table 3. Analysis of variance and mean values of commercial (CFP) and total (TFP) fruit production, commercial (CNF) and total (TNF) number of fruits, and commercial (CMFW) and total (TMFW) mean fruit weight

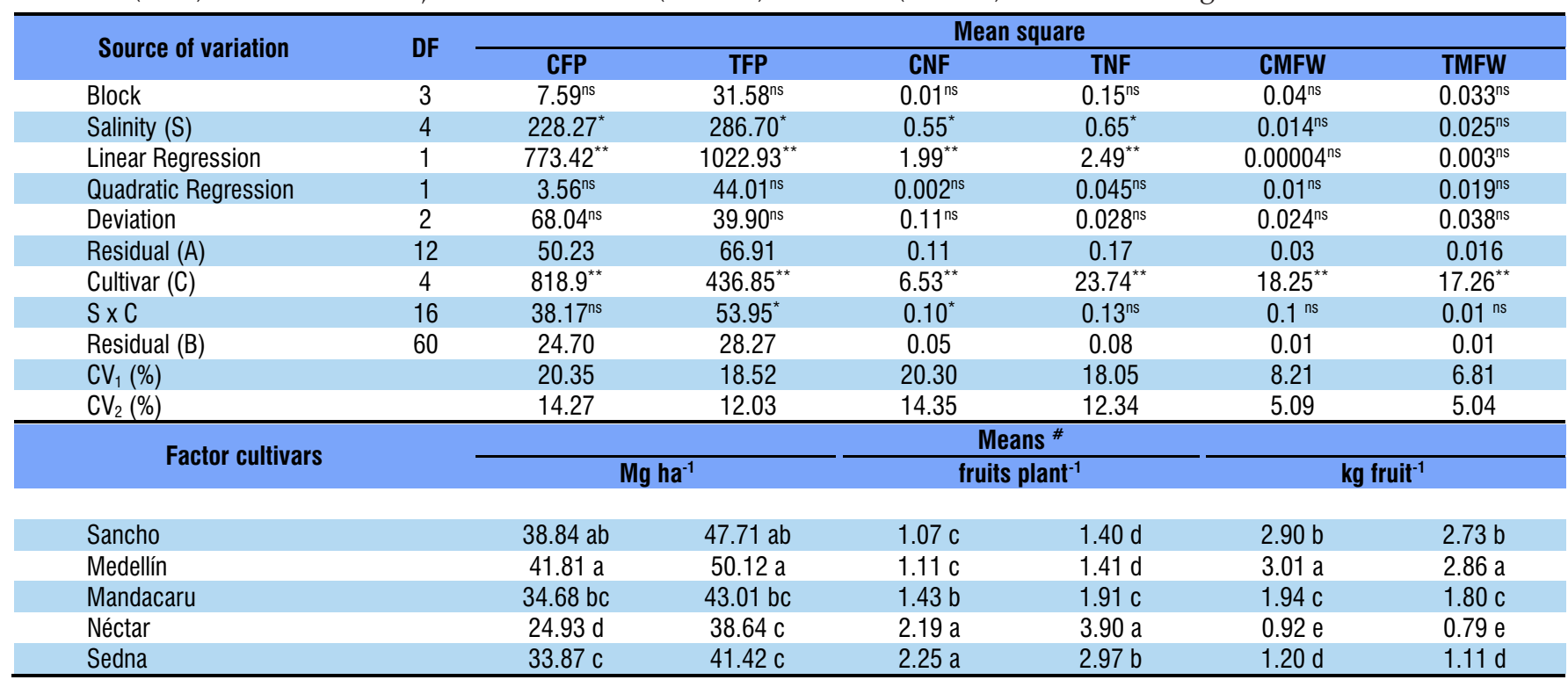

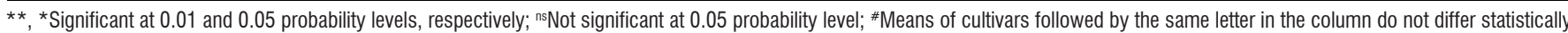
at 0.05 probability level by Tukey test 
cultivar Néctar produced more fruits (3.89 fruits plant ${ }^{-1}$ ) and was statistically superior to the others (Table 3 ).

Still regarding Table 3, the mean fruit weight of the Pele de sapo melon cultivars, Sancho and Medellín, distinguished from the others, with values of $3.00 \mathrm{~kg}_{\text {fruit }}{ }^{-1}$ (commercial) and 2.73$2.86 \mathrm{~kg}_{\text {fruit }}{ }^{-1}$ (total). For the others, MFW was equal to $1.80 \mathrm{~kg} \mathrm{fruit}^{-1}$ for Mandacaru and to 0.795 and $1.112 \mathrm{~kg}_{\text {fruit }}{ }^{-1}$ for Néctar and Sedna, respectively.

According to the ANOVA, there was a significant interaction at 0.01 probability level for commercial production and at 0.05 for total production (Table 3 ). The follow-up analysis of the effect of salinity for each cultivar indicated significant linear effect on the variables CMFW and TMFW for the cultivars Medellín, Néctar and Sedna $(\mathrm{p}<0.01)$ and Mandacaru $(\mathrm{p}<0.05)$, and non-significant effect for the cv. Sancho ( $p>0.05)$.

Hence, it can be inferred that the cv. Sancho is the most tolerant to salinity, reaching mean values of commercial and total production of 38.84 and $47.71 \mathrm{Mg} \mathrm{ha}^{-1}$, respectively (Figures $1 \mathrm{~A}$ and $\mathrm{C})$.

The cv. Medellín was the most sensitive to salinity, showing a reduction in commercial production from 47.8 to $35.6 \mathrm{Mg} \mathrm{ha}^{-1}$ when the $\mathrm{EC}_{\mathrm{w}}$ increased from 0.54 to $3.9 \mathrm{dS} \mathrm{m}^{-1}$ (loss of $3.61 \mathrm{Mg} \mathrm{ha}^{-1}$ or $7.55 \%$ per $\mathrm{dS} \mathrm{m}^{-1}$ ) and, for total fruit production, this reduction was equal to $4.61 \mathrm{Mg} \mathrm{ha}^{-1}$ or $7.98 \%$ per $\mathrm{dS} \mathrm{m}^{-1}$ (loss of $27 \%$ of total production) (Figure $1 \mathrm{~B}, \mathrm{C}$ and D).

Among the Pele de sapo cultivars, Medellín has higher absolute commercial fruit production up to the $\mathrm{EC}_{\mathrm{w}}$ of $2.93 \mathrm{dS} \mathrm{m}^{-1}$. From this point on, the cv. Sancho starts to have higher absolute commercial fruit production (Figure 1C).

The tolerance of the cultivars Sancho and Medellín was observed by Terceiro Neto et al. (2013), who evaluated the

A.

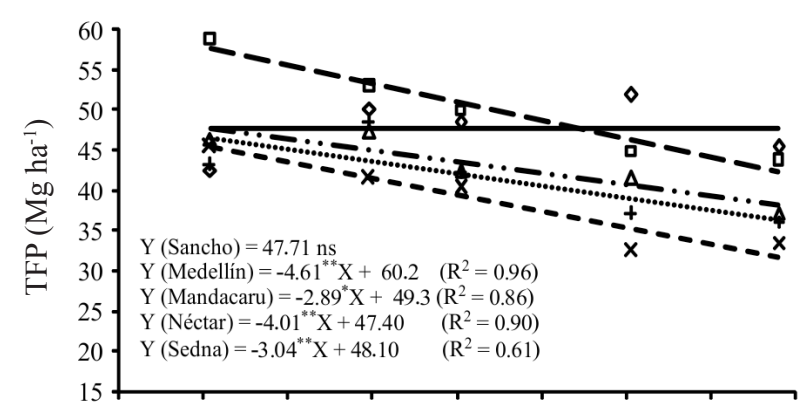

C.

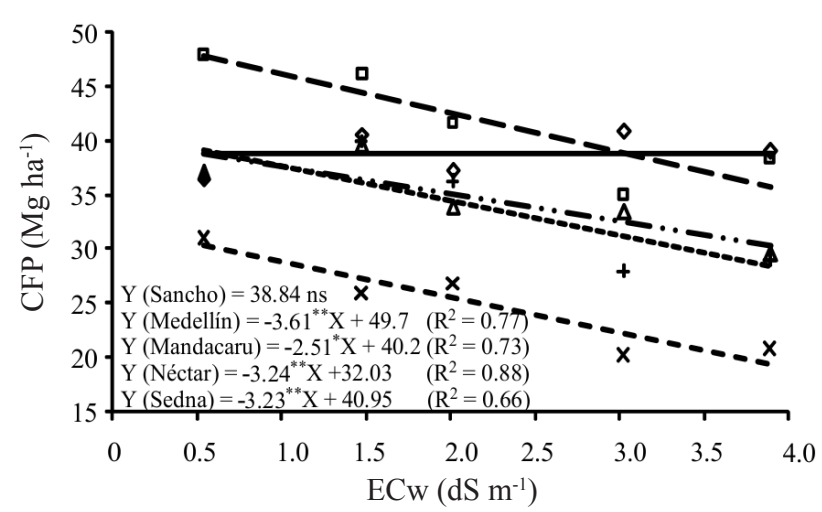

effects of irrigation with high and low water salinity level on melon cultivars under management strategies. Silva et al. (2005) studied the tolerance to salinity of two melon genotypes and found reduction of 15 and $36 \%$ in the commercial production of the hybrids Gold Mine (Canary) and Trusty (Cantaloupe) with $\mathrm{EC}_{\mathrm{w}}$ levels of 2.5 and $4.4 \mathrm{dS} \mathrm{m}^{-1}$, respectively, compared with the control treatment $\left(\mathrm{EC}_{\mathrm{w}}=1.2 \mathrm{dS} \mathrm{m}^{-1}\right)$.

Terceiro Neto et al. (2012) found significant differences in $\mathrm{Na}$ and $\mathrm{K}$ absorption and $\mathrm{K} / \mathrm{Na}$ ratio between the melon cultivars Sancho and Medellín. The authors concluded that, at high salinity levels, the cv. Sancho accumulated higher $\mathrm{Na}$ content in the stem and higher $\mathrm{K} / \mathrm{Na}$ ratio in the leaf tissue, compared with Medellín. This physiological strategy of the cv. Sancho can partially explain its higher tolerance to salinity in the present study.

According to Aktas et al. (2006), the ability of plant genotypes to maintain high $\mathrm{K}$ and $\mathrm{Ca}$ contents and low $\mathrm{Na}$ contents in the tissues is one of the main physiological mechanisms to express higher tolerance to salinity, i.e., salinity-tolerant genotypes can absorb higher contents of $\mathrm{K}$ and $\mathrm{Ca}$, maintaining high $\mathrm{K} / \mathrm{Na}$ and $\mathrm{Ca} / \mathrm{Na}$ ratios in the tissues. In some cases, genotypes most tolerant to salinity can accumulate higher contents of $\mathrm{Na}$ and $\mathrm{Cl}$ in the roots and/or plant stem tissues to be able to maintain the high $\mathrm{K} / \mathrm{Na}$ and $\mathrm{Ca} / \mathrm{Na}$ ratios in the leaves and, consequently, reduce the deleterious effects of salinity.

\section{Salinity tolerance curves for the studied cultivars}

By extrapolating the equations of Figure 2, it was observed that the estimated $\mathrm{EC}_{\mathrm{w}}$ values that reduce the relative production of the melon cultivars by $50 \%$ varied from 5.6 to $7.75 \mathrm{dS} \mathrm{m}^{-1}$, and the melon cultivars Néctar and Sedna showed higher sensitivity

B.

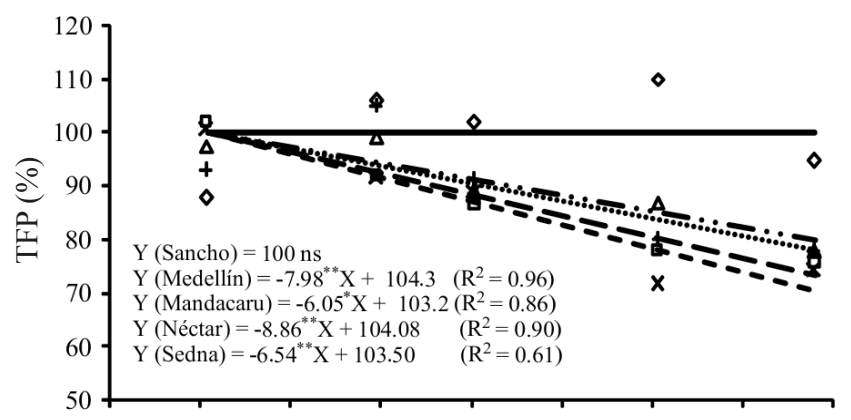

D.

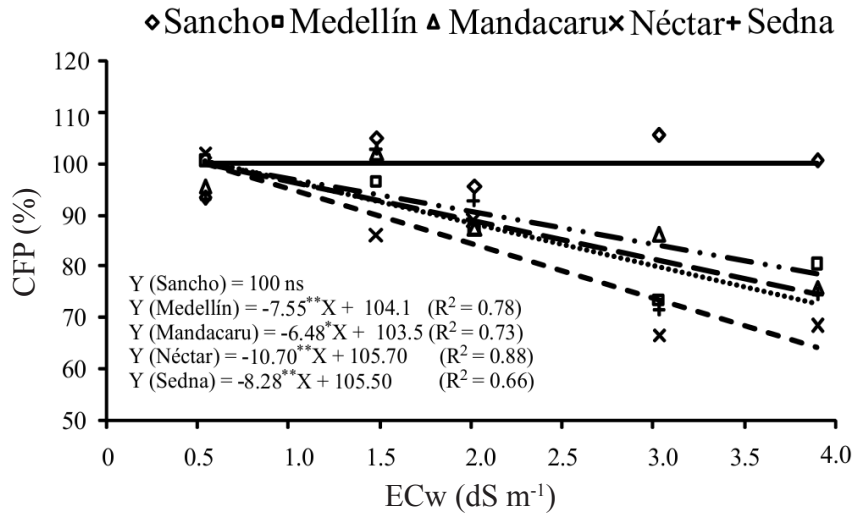

Figure 1. Absolute (A) and relative (B) total fruit production (TFP), and absolute (C) and relative (D) commercial fruit production (CFP), as a function of ECw for the studied cultivars 

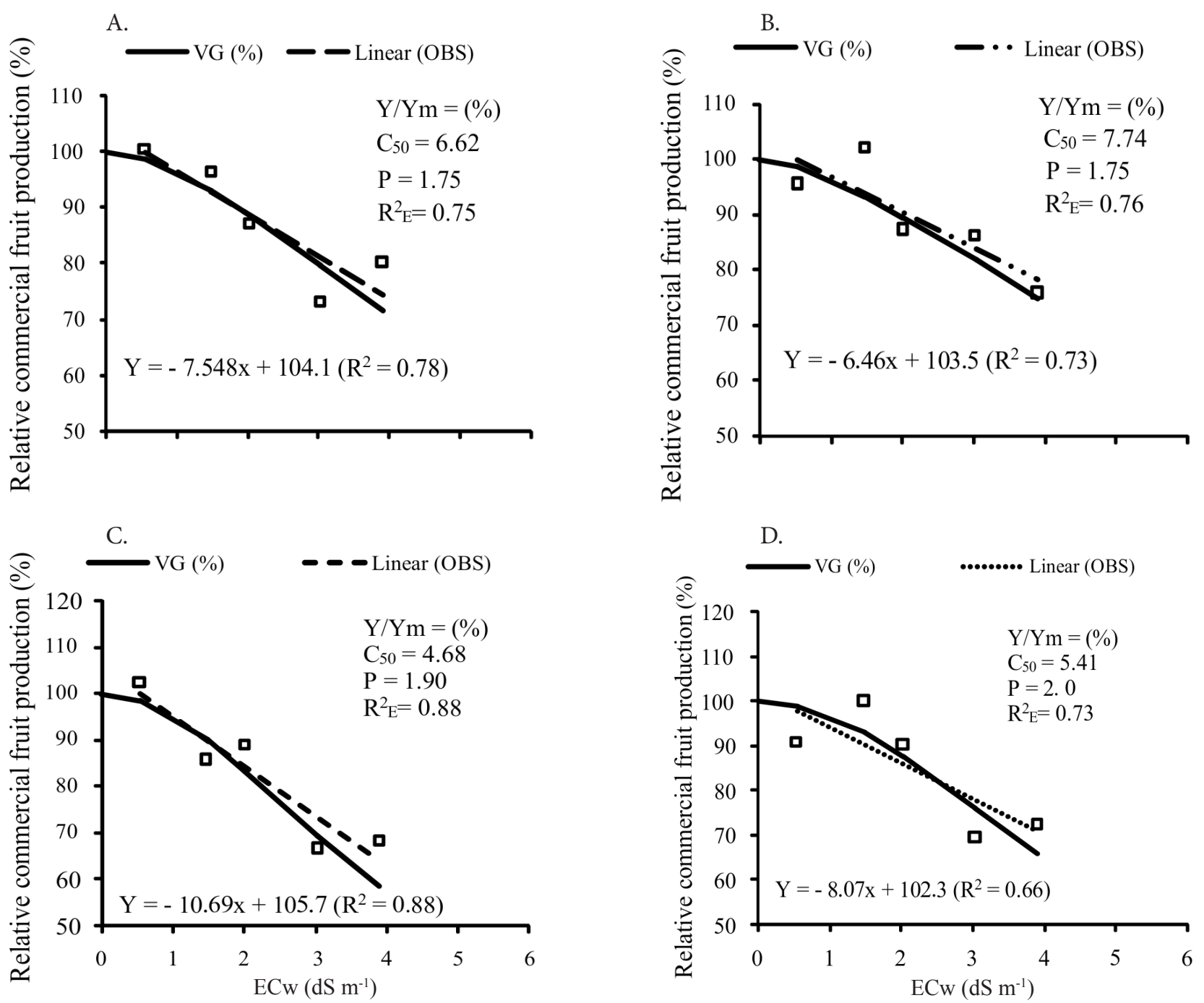

Figure 2. Relative production as a function of irrigation $\mathrm{EC}_{w}$ for the cultivars Medellín (A), Mandacaru (B), Néctar (C) and Sedna (D) using Linear (L) and Genuchten \& Gupta (1993) (VG) methods

to salinity, with losses of relative production from 4.7 and $5.4 \mathrm{dS}$ $\mathrm{m}^{-1}$ for Néctar and Sedna, respectively (Figure 2).

It should be highlighted that the model does not apply to the $\mathrm{cv}$. Sancho, because there was no reduction in its production with the increment in $\mathrm{EC}_{\mathrm{w}}$, thus not allowing to estimate the $\mathrm{EC}_{\mathrm{w}}$ that reduces the relative production by $50 \%$. However, for the other cultivars, the model was similar to the effect of the linear regression. The $\mathrm{R}^{2}$ estimated with the relative values and values found in the equations are similar to those of the linear regression and, in some cases, superior to those of the linear model (Figure 2).

\section{Post-harvest quality}

Only the variable total soluble solids (TSS) was influenced by irrigation water salinity $(\mathrm{p}<0.05)$ and varied from 8 to $10.19 \%$. The cv. Néctar showed the highest TSS content, followed by Sancho. The cultivars Sancho, Medellín and Sedna did not differ statistically, showing mean TSS values of 9.60, 8.95 and 9.23\%, respectively (Table 4).

The TSS contents of the Pele de sapo cultivars Sancho and Medellín were statistically equal (9.6 and 8.95\%, respectively), not differing from the cv. Néctar (Table 4).

Analysing the content of total soluble solids (TSS) in relation to the levels of irrigation water salinity, there was an
Table 4. Summary of the analysis of variance and mean values of total soluble solids (TSS) and pulp firmness

\begin{tabular}{|c|c|c|c|}
\hline \multirow{2}{*}{ Source of variation } & \multirow{2}{*}{ DF } & \multicolumn{2}{|c|}{ Mean square } \\
\hline & & TSS & Firmness \\
\hline Block & 3 & $6.64^{* *}$ & $23.67^{*}$ \\
\hline Salinity & 4 & $1.55^{\star *}$ & $5.32^{\text {ns }}$ \\
\hline Linear regression & 1 & $5.65^{* *}$ & $4.48^{\text {ns }}$ \\
\hline Quadratic regression & 1 & $0.00^{\mathrm{ns}}$ & $2.87^{\mathrm{ns}}$ \\
\hline Deviation & 2 & & \\
\hline Residual (A) & 12 & 0.25 & 6.10 \\
\hline Cultivar & 4 & $12.83^{\star \star}$ & $879.47^{\star \star}$ \\
\hline $\mathrm{S} \times \mathrm{C}$ & 16 & $0.60^{\text {ns }}$ & $5.89^{\text {ns }}$ \\
\hline Residual (B) & 60 & 0.62 & 5.93 \\
\hline $\mathrm{CV}_{1}(\%)$ & & 6.15 & 8.47 \\
\hline $\mathrm{CV}_{2}(\%)$ & & 8.56 & 8.92 \\
\hline \multirow{2}{*}{\multicolumn{2}{|c|}{ Cultivars }} & \multicolumn{2}{|c|}{ Means } \\
\hline & & $(\%)$ & (N) \\
\hline Sancho & & $9.60 a b$ & $21.10 \mathrm{~d}$ \\
\hline Medellín & & $8.95 b$ & $21.19 d$ \\
\hline Mandacaru & & $8.03 \mathrm{c}$ & $32.81 \mathrm{~b}$ \\
\hline Néctar & & $10.19 a$ & $35.53 \mathrm{a}$ \\
\hline Sedna & & $9.23 b$ & $25.86 \mathrm{c}$ \\
\hline
\end{tabular}

**, *Significant at 0.01 and 0.05 probability levels, respectively; " nsNot significant; Means of cultivars followed by the same letter in the column do not differ at 0.05 probability level by Tukey test

increment in TSS as water salinity increased $\left(\mathrm{TSS}=0.153 \mathrm{EC}_{\mathrm{w}}\right.$ $+8.86, \mathrm{R}^{2}=0.52$ ). 
Higher TSS content in fruits of plants irrigated with highsalinity water is probably due to the reduction in mean fruit weight caused by the deleterious effects of salts, which induced increase in the concentration of photoassimilates (solutes). On the other hand, the increment of photoassimilates in melon fruits irrigated with high-salinity water may also be associated with the reduction of water content in the fruit, caused by the difficulty in water absorption by plants in saline environment, as reported by Ayres \& Westcot (1985).

These results are consistent with those found by Medeiros et al. (2008), who observed higher TSS values in fruits of plants irrigated with brackish water, but differ from those found by Porto Filho et al. (2009), who observed that TSS contents were not influenced by the increasing levels of irrigation water salinity.

All studied cultivars showed mean TSS within the standards adopted by most melon-exporting countries as a marketing guideline, except for the cultivar Mandacaru. For commercialization in the USA, the ideal TSS content varies between 9 and 10 for Inodorus and Néctar and Sedna, respectively. In Europe, the recommendation is $10 \%$ for Cantaloupe, Canary and Orange Flesh, 11\% for Pele de sapo, $12 \%$ for Galia and 13\% for Charentais (Morais et al., 2009).

\section{Conclusions}

1. Among the five genotypes studied, Sancho was the most tolerant to salinity, followed by the cultivars Mandacaru, Medellín, Sedna and Néctar.

2. The reduction in the number of fruits per plant was the main cause of yield loss in the melon cultivars sensitive to salinity.

3. The contents of total soluble solids of the melon cultivars increased with the increment in irrigation water salinity.

\section{Literature Cited}

Aktas, H.; Abak, K.; Cakmak, I. Genotypic variation in the response of pepper to salinity. Scientia Horticulturae, v.110, p.260-266, 2006. https://doi.org/10.1016/j.scienta.2006.07.017

Allen, R. G.; Pereira, L. S.; Raes, D.; Smith, M. Crop evapotranspiration: Guidelines for computing crop water requirements. Rome: FAO, 1998. 297p. FAO Irrigation and Drainage, 56

Aragão, C. A.; Santos, J. S.; Queiroz, S. O. P.; França, B. Avaliação de cultivares de melão sob condições de estresse salino. Revista Caatinga, v.22, p.161-169, 2009.

Ayers, R. S.; Westcot, D. W. Water quality of agriculture. Rome: FAO, 1985. 174p. Irrigation and Drainage Paper, 29

Dias, N. da S.; Oliveira, A. M. de; Sousa Neto, O. N. de; Blanco, F. F.; Rebouças, J. R. L. Concentração salina e fases de exposição à salinidade do meloeiro cultivado em substrato de fibra de coco. Revista Brasileira de Fruticultura, v.33, p.915-921, 2011. https:// doi.org/10.1590/S0100-29452011005000084

EMBRAPA - Empresa Brasileira de Pesquisa Agropecuária. Manual de métodos de análise de solos. 2.ed. Rio de Janeiro: EMBRAPA, 1997. 212p.

Genuchten, M. T. van; Gupta, S. K. A reassessment of the crop tolerance response function. Journal of Indian Society of Soil Science, v.41, p.730-737. 1993.
Kim, H. J.; Fonseca, J. M.; Choi, J. H.; Kubota, C.; Kwon, D. Y. Salt in irrigation water affects the nutritional and visual properties of romaine lettuce (Lactuca sativa L.). Journal of Agricultural and Food Chemistry, v.56, p.3772-3776, 2008. https://doi.org/10.1021/ jf0733719

Kim, H.; Jeong, H.; Jeon, J.; Bae, S. Effects of irrigation with saline water on crop growth and yield in greenhouse cultivation. Water, v.6, p.2-9, 2016. https://doi.org/10.3390/w8040127

Medeiros, J. F. de; Dias, N. da S.; Barros, A. D. de. Manejo da irrigação e tolerância do meloeiro a salinidade da água de irrigação. Revista Brasileira de Ciências Agrarias, v.3, p.242-247, 2008. https://doi. org/10.5039/agraria.v3i3a264

Medeiros, J. F. de; Terceiro Neto, C. P. C.; Gheyi, H. R.; Dias, N. da S.; Souza, M. S. de M.; Souza, R. O. de. Management strategies of saline water on morphometric characteristics of melon cultivars. Engenharia Agrícola, v.34, p.649-659, 2014. https://doi.org/10.1590/ S0100-69162014000400005

Morais, P. L. D.; Silva, G. G. da; Maia, E. N.; Menezes, J. B. Avaliação das tecnologias pós-colheita utilizadas e da qualidade de melões nobres produzidos para exportação. Ciência e Tecnologia de Alimentos, v.29, p.214-218, 2009. https://doi.org/10.1590/S010120612009000100033

Nangare, D. D.; Singh, K. G.; Kumar, S. Effect of blending fresh-saline water and discharge rate of drip on plant yield, water use efficiency (WUE) and quality of tomato in semi arid environment. African Journal of Agricultural Research, v.8, p.3639-3645, 2013. https:// doi.org/10.5897/AJAR12.168

Plaut, Z.; Edelstein, M.; Ben-Hur, M. Overcoming salinity barriers to crop production using traditional methods. Critical Reviews in Plant Sciences, v.32, p.250-291, 2013. https://doi.org/10.1080/07 352689.2012.752236

Porto Filho, F. de Q.; Medeiros, J. F. de; Ferreira Senhor, R.; Morais, P. L. D. de; Menezes, J. B. Qualidade de frutos de melão amarelo irrigado com água de diferentes níveis de salinidade. Revista Caatinga, v.22, p.193-198, 2009.

Richards, L. A. (ed.) Diagnosis and improvement of saline and alkali soils. Washington D.C.: U.S. Salinity Laboratory. 1954. 160p. USDA Handbook, 60

Silva, M. C. de C.; Medeiros. J. F. de; Negreiros, M. Z. de; Sousa, V. F. de. Produtividade de frutos do meloeiro sob diferentes níveis de salinidade da água de irrigação, com e sem cobertura do solo. Horticultura Brasileira, v.23, p.202-205, 2005. https://doi. org/10.1590/S0102-05362005000200008

Terceiro Neto, C. P. C.; Gheyi, H. R.; Medeiros, J. F. de; Dias, N. da S.; Campos, M. de S. Produtividade e qualidade de melão sob manejo com água de salinidade crescente. Pesquisa Agropecuária Tropical, v.43, p.354-362, 2013. https://doi.org/10.1590/S198340632013000400007

Terceiro Neto, C. P. C.; Medeiros, J. F. de; Gheyi, H. R.; Dias, N. da S.; Oliveira, F. R. A. de; Lima, K. da S. Acúmulo de matéria seca e nutrientes no meloeiro irrigado sob estratégias de manejo da salinidade. Revista Brasileira de Engenharia Agrícola e Ambiental, v.16, p.1069-1077, 2012. https://doi.org/10.1590/S141543662012001000006 